\title{
Cumhuriyet Dönemi Kadın Dergileri (1923-1992)
}

\author{
DOI: 10.26466/opus.518421
}

\section{Selda Malkoç Kılıç ${ }^{*}$ Duygu Vefikuluçay Yılmaz ${ }^{* *}$}

* YL Öğrencisi, Mersin Üniversitesi, S.B.E. Kadın Araştırmaları Anabilim Dalı, Mersin/Türkiye E-Posta: seldamalkoc@erciyes.edu.tr

ORCID: 0000-0002-6348-8133

** Doç. Dr., Mersin Üniversitesi, Kadın Sorunları Araştırma ve Uygulama Merkezi. Mersin/Türkiye E-Posta: duyguulu@gmail.com

ORCID: $\underline{0000-0002-9202-8558}$

\section{Öz}

Bu derlemede Cumhuriyet dönemi kadın dergiciliği ve kadın dergileri incelenmiştir. Cumhuriyet öncesi kadın dergileri fikir anlamında hem kendi hem de batı karşısında kendini ispatlamaya çalışırken, Cumhuriyet sonrası kadın dergilerinde kadın daha ziyade fiziksel görünürlüğ̈̈nü kanıtlama çabasına girişmiştir. Bu değgişimi Cumhuriyet'in "Batılı Kadın" tanımlamasıyla örtüşen kadın dergilerinin içeriklerinde ve tasarımlarında görmek mümkündür. Bu durum toplumda kadına verilen değerin değişmesi olarak yorumlanabilir. Cumhuriyet dönemindeki kadın dergi içeriklerinde erkeklerle eşitlik mücadelesi, kendi ayakları üzerinde duran özgür kadın, aile hayatı, cumhuriyet kadın gibi konulara yer verilmiştir. Ayrica salt kadın bedeni ile kadın arzuların malzeme yapmayan, feminist hareketi benimseyen dergicilik anlayışına da rastlanmaktadır. Cumhuriyet dönemindeki kadın dergileri kadının eğitimi ve haklarını arama konusunda önemli rol oynamış, günümüz kadın haklarında önemli adımların başlangıcı olmuştur. Bu derlemede Cumhuriyet döneminin 1923-1992 yılları arası çıkarılmış olan kadın dergileri incelenerek kadınların genelde ve toplumu ve özelde kadınları ilgilendiren gelişmelere nasıl baktıkların ortaya koymak amaçlanmıştır. İncelenen kadın dergileri, ele aldığı konuların feminist düşünceye sahip olup olmaması gibi nitelikleri de ele alınarak seçilmiştir.

Anahtar Kelimeler: Kadın dergisi, Cumhuriyet dönemi, Kadın kimliği 


\title{
Women's Magazines in the Republican Period (1923-1992)
}

\begin{abstract}
In this review, women's magazine publishing and women's magazines of the Republican era were examined. While women's magazines of the pre-republican period have tried to prove themselves in terms of ideas both in their own eyes and before the West, the women with whom we encounter in the post-republican women's magazines seem to have attempted to prove their "physical visibility" being. It is possible to see this change in the contents and designs of the women's magazines that coincide with the "Western Women" definition of the Republic. This situation can be interpreted as the change in the value attributed to women in society. The content of the women's magazines in the Republican era included the struggle for equality with men, free women standing on their own feet, family life and the woman of the republic. Besides, it is possible to encounter with an understanding of magazine publishing that adopts the feminist point of view and not exploit the female body and female desires. Women's magazines in the Republican era played an important role in the education of women and their quest for rights and happened to be the first steps in the attainment of the current status of women's rights. In this review, it is aimed to examine the women's magazines published between the years of 1923-1992 and how women look at the developments that are related to women and society in general and women in particular. The women's journals examined were selected by considering the issues such as whether they have feminist thoughts or not.
\end{abstract}

Keywords Women's magazine, Republican period, Women's identity 


\section{Giriş}

Cumhuriyet döneminde kadın dergiciliği, ülkede yapılan inkılapların ve Batı'nın toplumun her yönüne etki etmeye başlaması ve gerekse sektörel canlanmalar gibi nedenlerle yavaş yavaş kabuk değiştirmeye başlamıştır. Kadının gerek siyasi alanda haklar elde etmesi, gerek eğitim eşitliğinin sağlanması yönünde adımlar atılması, gerekse kadının çalışma yaşamında var olmaya başlamasıyla birlikte kadınlar çeşitli alanlarda görünür olmuşlardır. Kadınlar Cumhuriyet dönemi öncesinde dergilerde fikirsel alanda hem kendi ülkesinde hem de Batı karşısında varlıklarını ispatlamaya çalışırken bu doğrultuda haklarını arayan mektuplar ve makaleler yazıp "biz de varız" mesajını verirken; Cumhuriyet sonrasında ise "kadın" daha çok fiziksel görünürlügünü da kanitlama gayretine düşmüştür. Bu da Cumhuriyet'in "Batılı kadın" tanımlamasından hareketle kadının yavaş yavaş görünür olmasından kaynaklanmıştır (Mutlu, 2009, s.59).

Cumhuriyet'in ilan edilmesi sonrasında kadın, Osmanlı döneminde olduğu gibi, kendisi için bazı haklar elde etmek için uğraşan, kendisinin de birey olduğunu kanıtlamaya çalışan, toplumun her kesiminde kadın ve erkeğin eşit olduğunu savunan, bunu eleştiren, tartışan ve tartan kadın kimliği ile yer almak yerine, fiziksel görünürlüğünü kantlama yolunda yazılarıyla yer almaya çalışmışlardır.

Cumhuriyet döneminde kadınların Osmanlı dönemindeki gibi kimlik mücadelesi kaygılarının az olması veya hiç olmamasının sebebinin kadınlara sadece çeşitli hakların verilmesi değil ekonominin dinamiklerinde oluşan değişimlerin de payı azımsanamaz. Görülen bu değişimler kadın dergilerinin sayılarında, yayımlanma aralıklarında, dergilerin tasarımlarında, dergi içeriklerinde farklılaşmaya yol açmıştır. Kadın dergileri de diğer yazılı materyaller gibi toplumun değişen değeri hakkında bilgi veren önemli kaynaklardan sayılmıştır (Mutlu, 2009, s.60).

Cumhuriyet'in ilanı sonrasında çeşitli dergilerde kadın ve erkeğin dayanışması gerektiğini, kadına siyasal hakların da verilmesinin gerekli olduğunu savunan yazılar çıkmıştır. Nezihe Muhittin Türk Kadın Yolu dergisinin ilk sayısında "Kadın Yolu Şiarı" adlı yazısında seçme e seçilme hakkını bir "vazife-i medeniyet" olarak tanımlamıştır. Ayrıca dergide Batılı ülkelerin kadınlara oy hakkı verdiğini, bazı hükümetlerin de 
belediye seçimlerine katılma gibi sınırlı haklar vererek kadına ikidar olma yolunun açıldığını anlatan yazılara da dergide yer veriliği bilgisine ulaşılmıştır (Özen, 1990, s.36).

Cumhuriyet'in ilanı ile birlikte açıkça kadın hakları ve feminizm konusu tartışılmaya başlanmıştır. Beyhan adlı bir yazarın "Kadın haklarının esirgenmesinden: feminizm ve terbiye-i beytiyeye ait bir mukaddime" (1923) başlıklı yazısı tek sayı yayınlanan Ev Hocası adlı dergide kaleme alınmıştır. Yine yazarı beli olmayan "kadınlık şuuru: Türk kadınlarının ilk siyasi hareketi" başlıklı bir yazı da dergide yer alır. Öte yandan Süs dergisinin devamı niteliğinde iki sayı çıkan Firuze (1924) "dünya kadın hareketleri" başlığıyla kadın hareketleri ile ilgili çeşitli fotoğraflara yer vermiştir (Şahin, 2018, s.97).

Kadın dergileri alanında çalışma yapan Aslı Davas Mardin "Hanımlar Alemi'nden Rosa'ya" adlı bir bibliyografya çalışması yapmıştır. Bibliyografyada 1928 yılından 1996 yılına kadar olan süreli yayınları toplayarak, 1928-1996 yıllarını 10 yıllık dönemlere ayırmıştır. Bu bibliyografyaya göre 1928 yılında hiçbir kadın dergisine rastlanmamıştır. 1929 yılında Hanımlar Alemi'ne rastlanmıştır. 1930-1940 yılları arasında 12, 1940-1950 yılları arasinda 17, 1950-1960 yılları arasinda 22, 1960-1970 yılları arasında 16, 1970-1980 yılları arasında 22, 1980-1990 yılları arasında 44, 1990-1996 yılları arasında 63 dergi yayımlanmıştır (Mardin, 1998, s.15).

1928-1996 yılları arasında yayınlanan 195 derginin yayımlanma periyotları birbirinden farklıdır. Bazı yayınlar günlük, bazıları haftalık, bazıları 15 günlük, bazıları aylık, bazıları iki aylık, bazıları da üç aylık periyotlar halinde yayımlanmıştır. Aslı Davas Mardin'in çalışmasına göre, çıkan yayınların yayım sorumluları ve sahiplerine bakıldığında 1947 yılına kadar kadın dergi ve gazetelerinde yayın sorumlusu ve sahibi kadın olan bir yayına rastlanmamıştır. Sadece 1940 yılında Adana Kız Lisesi öğrencilerinin yazılarının yayınlandığı Sesimiz dergisinin Genel Yayın Yönetmeni olarak Belkıs Zincirkıran adına rastlanmıştır. Sahibinin ve yayın sorumlusunun kadın olduğu iki dergiye 1947 yılında rastlanmıştır. Bu yayınlardan ilki, sahibi ve başyazarı İffet Halim Oruz olan, sadece cumartesi günleri çıkan, haftalık gazete "Kadın Gazetesi", ikincisi ise sahibi ve Yazı İşleri Müdürü Nezihe Saim Güngör olan "Güngör" gazetesidir (Mardin, 1998, s.19). 
Aslı Davas Mardin, 1928-1996 yılları arasında çıkarılan dergileri konularına göre beş ana başlık altında incelemiştir. Birinci başlıkta giyim modası, güzellik, bakım, fotoroman, ikinci başlıkta din konularını işleyen yayımlar, üçüncü başlıkta anne-çocuk konularını ele alan yayınlar, dördüncü başlıkta mesleki yayımlar, son başlıkta ise fikir yayımları olarak sıralamak mümkündür (Mutlu, 2009, s.61).

Kadın dergileri II. Meşrutiyet döneminde ciddi bir gelişme göstermiştir. Bu dergiler, kadınların kendilerini ifade etmesinde önemli bir görev üstlenmiştir. 1928'e kadar toplam 33 derginin varlığını tespit edilmiştir (Aşa, 1989, s.22). Ayrıca Aynur Demirdirek'in yapmış olduğu bir çalışmaya göre Cumhuriyet'e kadar 40'ın üzerinde kadınlara yönelik çalışmanın bulunduğu dile getirilmektedir (Demirdirek, 1993, s.8).

Cumhuriyet'in kurulmasindan sonra 1928-1940 yılları arasında kadın dergilerinde düşüşün yaşandığı görülmektedir. Bu süre zarfında 13 dergi yayınlanmıştır. Düşüşün ebebine bakıldığında 1928 yılında Latin Alfabesi'nin kabul edilmesi ve kadının kamusal alanda yavaş yavaş dine yer edinmeye başlamasıdır (Schroeder, 2007, s.138).

Kadın okurlara yönelik dergiler ağırlıklı olarak 1930'lardan sonra ortaya çıkmıştır. Bunlara; Elişi (1930),El Emekleri, Aile Dostu (1931), Salon, Cumhuriyet Kadını (1934), Moda Albümü (1936), Model (1937), Ev-IŞ (1937), Okul Kızı (1937), Ana (1938), Sesimiz (1940), Kadın Dünyası (1940), Kadınlar Âlemi (1940), Ev-Kadını (1943), Asrın Kadın (1944), Ev Kadını (1945), Aile (1947), Kadın Gazetesi (1947), Hanımeli (1947), Yeni Moda (1948), Seksoloji (1949), Yeni Holivud Magazin (1948), Büyük Moda Mecmuası (1949), Familya (1949), Dişi Kuş (1949), Hemşirelik Dergisi (1950), Yelpaze (1952), Resimli Hayat (1952), Yelpaze (1953), Türk Kadın (1966) ve Hafta Sonu (1967) örnek verilebilir (Şahin, 2018, s.99).

Kadın dergileri 1970'lere kadar zamanla siyasi değişimlerle birlikte, kadın merkezli olmaktan ziyade; aile merkezli kültürel dergiciliğe dönüşse de, magazin, yemek, moda, güzellik, elişi gibi konular dergilerin ağırlıklı odak noktası olur. Gerek çalışan kadınlara gerekse ev kadınlarına yönelik çıkan dergiler bir tür magazinciliğe dönüşür, ancak 1970 sonrası ikinci dalga feminizm ile birlikte dünyadaki gelişmelere paralel olarak feminist mücadelelerle beraber Türk kadın kimliği, erkeğin dünyasında kadının yeri sorgulanmaya ve kadınlık meseleleri tartışılmaya başlanmıştır. Sağ- 
lık, çocuk bakımı, moda, güzellik gibi meselelerin yanında öğrenci ayaklanmaları, siyasi çatışmalar, çalışan kadın hakları, erkeklerle eşit ücret meseleleri, cinsel istismar, şiddet ve doğum kontrolü Kadınların Sesi (1974), Elele (1976), Kadınca (1978) gibi dergilerde ele alınmıştır (Şahin, 2018, s.99).

1980 yılına gelindiğinde feminist hareketlerin temelinde güçlenen kadın hareketleri kadın dergiciliğini de etkilemiştir (Mardin, 1998, s.139). Feminist akım ve liberal politikaların 1980 yılında kendini göstermesiyle birlikte yayım sektörü etkilenmiş, çıkarılan yayınların içeriklerinde ve görüntülerinde çeşitli değişimler meydana gelmiştir. 1980 yılı ve sonrasında kadın dergileri el işi örnekleri, iyi yemek pişirmenin püf noktaları, annelik, iyi bir ev kadını olmanın yolları gibi konuların yanında çalışma hayatında kadın, flört, eğitim gibi konuları da ele alarak "liberal söylemin biçimlendirdiği modern şehirli kadına" hitap etmişlerdir (Schroeder, 2007, s.140).

Feministlerin gözüyle bakıldığında 12 Eylül 1980 askeri darbesi, kadınların örgütlenmesi, seslerini duyurması ve feminist söylemlerin alevlenmesinde bir bakıma çıkış noktası olmuştur. 1980'li yıllarda kadına yönelik şiddete hayır kampanyalarn ile her türlü şiddet protesto edilmiştir. Ankara'da ve İstanbul'da "Bedenimiz Bizimdir" "Cinsel Tacize Hayır" kampanyaları "mor iğne" ile ses getiren bir güce dönüşür." (Altınay ve Arat, 2007, s.18). Böylece tüm ülke genelinde "Adana, Antalya, Mersin, Gaziantep, Diyarbakır, Samsun, Eskişehir ve daha birçok kentte kadın hareketinin sözü ve savunduğu feminist fikirler yayılmaya başladr." (Kardam ve Ecevit, 2007, s.90).

1980'lerden sonra kadınların haklarını elde etmeleri için çabalayan dergiler zamanla yerini; erkek tekelinde ya da erkek bakış açısıyla çıkan kadın dergilerine bırakır ve "kadın bedeni" cinsel bir objeye dönüşmüştür. Çıplak kadın resimleri ve kapak kızları ile satış rekoru kıran aktüel dergiler ayrı bir cinsiyet pazarı oluşturmuştur. Gerek yerli gerekse yabancı dergiler, kadınlar üzerinde satış yaparak yayın politikalarına kadınları alet etmişlerdir. Bunun yanında iş kadınlarına yönelik idealist dergiler de basın dünyasında yerlerini almışlardır. Süheyla Kırca Schroeder'in de söylediği gibi "Amica, Options, Cosmopolitan, Votre Beautâ, Prima Donna gibi bu yeni dergiler, öncekilerden daha sofistike, şık, renkli ve cazip görünüyordu." (Schroeder, 2007, s.140) durum böyle olunca, kadın deneyimlerinden ziyade, kadınların gerek yazılı gerekse görsel medyada cinsel obje 
olarak pazara çıkarılışı günümüzde dahi kabul edilir bir gerçek olarak karşımıza çıkmaktadır (Şahin, 2018, s.100).

Feminist kadın sayfalarını ik olarak Yazko'nun haftalık çıkarmış olduğu Somut dergisinde görülmüştür. Ayrıca Kadın Çevresi (1984), Kadın ve Aile (1985), Mektup (1985) gibi kadın dergilerinde de görmek mümkündür (Şahin, 2018, s.99).

1990'lı yıllara gelindiğine kadın meseleleri bilimsel boyutlara ulaşmıştır. Üniversitelerde Kadın Araştırma Merkezleri açılmıştır. Çoğu merkez kadın araştırmaları ile ilgili yayın organı oluşturmuştur. Örnek olarak İstanbul Üniversitesi Kadın Araştırma Merkezi'nin Kadın Araştırmaları Dergisi'ni gösterebiliriz (Şahin, 2018, s.100).

1990'lı yıllara gelindiğinde kadın dergilerinin piyasasında bir artışın olduğu gözlemlenmiştir. En çok dergi 1990'lı yılların sonunda yayınlanmıştır. Mardin'in çalışmasını incelediğimizde bu dönemde 60'ın üzerinde kadın dergisine rastlamaktayız. Bu dergilerin sadece ticari faaliyet gösteren dergiler değil, bazı kurum kuruluş veya derneklerin yayın organları olduğu görülmektedir. 1990'lı yılların sonunda yayınlanan dergiler yine anne-çocuk, eşitlik, moda, güzellik, elişleri, Kürt kadınlarının kimliği, İslamı kadınlar, çalışan kadın vb. konuları işlemiştir (Mutlu, 2009, s.62).

Türkiye'de teknolojinin gelişmesiyle birlikte kadın dergiciliği de hız kazanmıştır. Önceki yıllarda görsel açıdan ve dergi kağıdı açısından bakıldığında dergilerde son yıllarda daha kaliteli malzemelerin kullanıldığ1 görülmektedir (Mutlu, 2009, s.63). İncelenen dergilerde aile hayatı konusuna Süs dergisinde, kadın erkek eşitliği gibi konulara Kadın Yolu ve Kim dergilerinde, özgür kadın konularına Kadınca dergisinde ele alındığı görülmektedir.

Bu derlemede Cumhuriyet döneminin 1923-1992 yılları arası çıkarılmış olan kadın dergileri incelenerek kadınların genelde ve toplumu ve özelde kadınları ilgilendiren gelişmelere nasıl baktıklarını ortaya koymak amaçlanmıştır. Ayrıca bu dönemin kadınlarının kendilerinden önceki kuşağın başlatmış olduğu kadın hareketinden farklılıklarının olup olmadığının araştırılması ve bu dönem öncesi kadın dergilerinden işledikleri konuların farklılığı nedeniyle aşağıda adı geçen dergiler incelenmiştir. Aşağıdaki incelenen kadın dergileri, ele aldığı konuların feminist düşünceye sahip olup olmaması gibi nitelikleri de ele alınarak seçilmiştir. 
Aşağıda incelenen dergileren başka 2000'li yıllarda Aile, Ailem ve Ben, Alem, Anne ve Bebek, Bazaar, Bebeğim ve Biz, Burda Cosmogirl, Elele, Estetica, Female, Haftasonu, Hello, Heygirl, Instyle, Lezet, Modamag, Semerkand, Seninle, Sofra, Şebnem, Şamdan, Vogue gibi dergilerin de çıkarılmş olduğunu görmekteyiz (Şahin, 2018, s.100). Günümüze bakıldığında bilimsel amaçlı üniversitelere bağlı olarak Kadın Araştırmaları Merkezlerince çıkarılan Kadın Araştıraları Dergisi: Kadın/Woman 2000, Fe Dergisi, Petrol- İş Kadn gib kadın dergileri bilimsel, toplumsal ve siyasi boyutta önemini korurken; gerek gazete ekleri olarak gerekse bağımız olarak çıkan kadın, cinsellik, güzellik, sağlık ve moda içerikli Heygirl, CosmoGirl, Cosmopolitan, Elele, Elle, Vizon, Seninle gibi dergilerin çok fazla sayıda olduğu, popüler bir çizgide yayınlarını sürdürmekte olduğu görülmektedir (Şahin, 2018, s.101).

\section{Süs (1923)}

Cumhuriyet'in ilk kadın magazin dergisi Süs, "Haftalık Edebi Hanım Mecmuasıdır" tanıtımı ile 16 Haziran 1923'te İstanbul'da yayın hayatına başlamıştır. Derginin Sorumlu Müdürü Mehmet Rauf'tur. Dergicilik alanında promosyonu ilk uygulayan olması açısından da Süs Dergisi'nin önemi büyüktür. Dergide sinema artistleri yarışması, çocuk güzellik yarışması, en çok okunan roman gibi yarışmalar da düzenlenmiştir. Mehmet Rauf'un Mehasin Dergisi ile karşılaştırıldı̆̆ında Mehasin'de sosyal ve siyasal meseleler tartışılırken; Süs Dergisi'nde ağırlıklı olarak moda, ev ve aile hayatı, günlük yaşam konuları işlenmiştir. Süs dergi- sinin önemli özelliklerinden biri de ünlü tiyatro yazarı Müsahipzâde Celâl'in moda illüstrasyonlarına yer vermesi ve böylece dönemin moda algısını ve gelişimini göstermesidir (Karabacak, 2009, s.13).

Süs'ün yeni yayınlanmaya başladığı dönemler Nezihe Muhiddin Kadınlar Halk Fırkası'nı kurmaya çalıştığı döneme rastlamaktadır. Fakat dönemin hükümeti tarafından kurulması uygun görülmemiştir. Süs tam da Cumhuriyet'in oluşturmaya çalıştı̆̆ çalışmıştır. Kadının annelik vasıflarından ayırmayarak okuyan, öğrenen, çalışan, kendine bakan (yani süslenen, modayı takip eden) tam anlamıyla modern bir tablo çizmeye çalışmıştır (Mutlu, 2009, s.64). 


\section{Firuze (1924)}

Firuze Cumhuriyet'in ilanından sonra yayımlanan ilk kadın dergisidir. İki sayı olarak yayınlanmıştır ve kendisini Hanımlara mahsus haftalık edebi mecmua olarak tanıtmış, başyazarı Muazzez Yusuf olan dergi kendisinin "Süs" dergisinin devamı olduğunu belirtmiştir (Toska, 1992, s.34).

Derginin yayınlanmış olan iki sayısına da bakıldığında edebiyata ağırlık verdiğini görmekteyiz. Dergide yer alan konular kısaca şöyledir: Bürokraside yer alan kadınlarla mülakatlar, kadın ressamlar hakkında bilgiler, güzel bir vücuda sahip olmanın kuralları vb. Firuze iki sayı çıktığ 1 için, hakkında çok fazla bilgi sahibi olmak mümkün görülmemektedir (Mutlu, 2009, s.63).

\section{Kadın Yolu Dergisi (1925)}

Bir sivil toplum kuruluşu olan Türk Kadın Birliği'nin yayın organıdır (Mutlu, 2009, s.64). Cumhuriyetin ilan edilmesinden Harf İnkılâbı'na kadar olan beş yıllık süre içerisinde yer alan çeşitli dergiler arasında Kadın Yolu'nun seçilmesinin nedeni derginin sıradan bir kadın dergisi olmamasından kaynaklanmıştır. Dergiyi özel kılan ise Yaprak Zihnioğlu'nun belirttiği gibi derginin çıktığı dönemde cinsiyetçi zihniyet ve uygulamalara karşı ideolojik bir mücadele vermesi ayrıca Cumhuriyet'in ilanı sonrası direkt kadınları ilgilendiren bir takım reformlarda azımsanmayacak düzeyde etkisinin olmasıdır (Zihnioğlu, 2003, s.171).

Kadın Yolu Dergisi'nin ideolojik mücadele vermesinde sadece yayın politikası ve amacının gereği olmasının yanında bir sivil toplum kuruluşunun (Türk Kadın Birliği) yayın organı olmasından da kaynaklanmaktadır. Fakat Kadın Yolu Dergisi hiçbir zaman muhalefete yönelik sert tutumlar içerisinde olmamış bilakis muhalefete yönelik ılımlı politikalar izlemiştir. Bu ılımlı tavrıyla da kadınların çeşitli haklar elde etmesinde belirgin düzeyde etkisi olmuştur (Mutlu, 2009, s.64).

Dergide Batılı ülkelerin kadınlara oy hakkı verdiğini, bazı hükümetlerin belediye seçimlerine katılma gibi sınırlı haklar vererek kadına iktidar yolu açtığını dile getiren yazılara yer vermiştir (Özen, 1990, s.36) 


\section{Cumhuriyet Kadını (1934)}

15 günlük bir dergi olan Cumhuriyet Kadını Nisan 1934'e kadar yayın hayatını sürdürmüştür. "Cumhuriyet Kadını Neden Çıkıyor" başlıklı bir yazıda "Yeni bir mecmua çıkarmak isteyenler ya her nedense kadının bir varlık teşkil edebilecek bir kâri zümresi olmadiğına kanidirler. Yahut ta kadın kâri okumak ve öğrenmek ihtiyaçlarının bir kadın mecmuası çıkartacak kadar mühim olmadığı ve onlara yevmi gazetelerde bir kadın sahifesi yapttrarak ve bazen de mecmualarda, kadınlığa dair bir iki söz yazarak ve bir iki model göstererek bu ihtiyacın tatmin edildiğini zannediyorlar... Hâlbuki biz kadınlar için bu kadar basit olmadığın biliyoruz çünkü mesela bütün kadınların en masum ve en haklı arzusu ile modayı takip etmek için hem fazla para vererek ecnebi gazeteleri satın almak hem de onları anlayabilmek için muhakkak bir ecnebi lisanı bilmek mecburiyetindeyiz" diye belirtilmiştir (Mardin, 1998, s.15). Derginin ana teması her alanda uğraş veren çok yönlü kadın olarak dile getirilmiştir (Özen, 1990, s.38).

\section{Elle Dergisi (1945)}

Türkiye'de Hachette Filipacchi Medias Group'un lisansiyla Doğan Burda Dergi Yayıncılık ve Pazarlama A.Ş. tarafından 21 Kasım 1945 tarihinde yayınlanmıştır. İlk sayısının kapağı çizimden oluşmuştur. Moda, güzelik, sağlık, eğlence konulu bir Franız dergisi olup dünyanın en çok satan dergilerinden biridir. Pierre Lazareff ile eşi Helene Gordon tarafından kurulmuştur (https://tr.wikipedia.org/wiki/Elle_(dergi). II. Dünya Savaşı'n dan hemen sonraki dönem Fransız basını için bir Tabula Rasa (Beyaz Sayfa) dönemi olarak kabul edilmiştir. Çünkü savaştan önce var olan basın grupları, savaş sonrası ortadan kalkmış ya da yasaklanmıştır. Marie Clarie'de geçici bir süre için Fransız pazarında olmamıştır. Savaş öncesi dönemde derginin Yazı İşleri Müdürü Pierre Lazareff' in eşi Helene Gordon Lazareff "Elle" adında yeni, haftalık bir dergi çıkartmıştır (Giet, 2006, s.32).

Derginin konu başlıkları ise moda, güzellik, sağlık, aşk ve seks, psikoloji, astroloji, ayın röportajı, adreslerden oluşmaktadır. Genç kesime hitap eden dergi aşk, seks gibi konular başta olmak üzere kadın okuyucularına tavsiyelerde bulunmuştur. Elle Dergisi'nde kadın cinsel kimliği ile 
ele almıştır. Dergi çalışan, bakımlı, erkek ilişkilerindeki sınırı kendi belirleyen kadın imajı çizmiştir.

\section{Hanımeli (1947)}

Kadın dergileri arasında önemli bir yere sahip olan dergisi Ocak 1947'de Halil Lütfi Dördüncü tarafından İstanbul'da yayınlanmştır. Bu dergi, Cumhuriyet yıllarının idealist yaklaşımını sürdürür. Oldukça zengin bir içeriğe sahiptir. Kadın okurlara sayfalarını acmış ve dünya kadınlarına ilişkin haberlere yer vermiştir. Dergideki yazılarında Munir Hayri Egeli, Türk kadınının haklarını çok kısa zamanda ve diğer ülkelere oranla zahmetsiz elde ettiğini belirtmiştir (Özen, 1990, s.40)

\section{Resimli Hayat (1952)}

Şevket Rado tarafından çıkarılmıştır. Çok renki kuşe kapaklarında önde ve arkada güzel kadın artist fotoğraflarını kullanan bir kadın dergisidir. Yayın politikasını kadına yönelik konulara ağırlık vermesinin yanında tüm aile bireyleri tarafından okunabilecek bir niteliğe sahip olmak oluşturmuştur (Özen, 1990, s.46).

Bu dergi Cumhuriyet'le birlikte yeni bir kimliğe bürünen kadın tipine, klasik müzik dinleyen, ünlü yabancı yazar ve kişileri merak eden, okura hitap eden bir dergidir (Özen, 1990, s.47).

\section{Kadınca Dergisi (1978)}

1978 yılı Aralık ayında yayın hayatına başlayan Kadınca'nın Genel Yayın Yönetmeni Duygu Asena, Sorumlu Yayın Müdürü Muhittin Sirer'dir. Dergi kendisini "Aylık kadın dergisidir" şeklinde tanıtmıştır (Mardin, 1998, s.211). Kadınca Dergisi Türkiye'de kadınlığ1 erkek söyleminin dışında tanımlamaya çalışan ender bir popüler medya örneğidir (Tekeli, 1990, s.221).

Kadınca Dergisi şehirlerde yaşayan ev kadınlarına hitap eden bir dergi olarak yayın hayatına başlayan dergi daha sonra radikal feminist olarak tanımlanan Duygu Asena ve ekibinin yayını devralmasıyla daha feminist bir görüntü çizmiştir. Kadının sadece eve bağlı olmadığını, dışarıda da bir 
hayatının olduğunu, iyi giyinmenin ve bakımlı bir vücuda sahip olmanın sadece erkek için değil kadının kendisi için de önemli olduğu sık sık vurgulanmıştır. 1980'li yıllarda feminizmin sokak gösterileri ile kendini duyurmaya çalıştığ1 dönemlerde kadına yönelik şiddet ve her türlü ayrımcılığa karşı yapılan protestolar "Kadınca"da geniş yer bulmuştur. Dergi, böylece feminist düşüncenin tam olarak desteklendiği bir yayım olmuştur (Schroeder, 2007, s.157).

\section{Rapsodi (1988)}

Sayfalarında röportajlara, araştırma, inceleme yazılarına, sağlık, güzellik, moda, dekorasyon ve yemek tariflerine yer veren dergi Kasım 1988'de İstanbul'da yayınlanmıştır. Röportajlarda, daha çok o aylarda popüler olan sanatçı veya yazarlar yer almıştır. Sağlıkla ilgili konularda ise, bazı hastalıkları tanıtmakta ve o hastalıkla ilgili ne yapılması gerektiği konusunda yol göstermektedir. Ayrica her ay, "Rapsodi Takvim, Flash Back, Bir Kadın, Bir Erkek, Sohbet, Sen, Ben ve Diğerleri, Çehreler-çevreler, Rapsodi Mektup, Rapsodi Seçmeler" gibi köşeler değişmez sayfalarındandır. "Rapsodi Takvim" sayfasında, sinema, kitap, müzik, video, tiyatro vb. konulara yer vermiştir. "Bir Kadın" ve "Bir Erkek" sayfalarında ise hikâye veya düzyazı biçimindeki anlatılar dikkati çekmektedir. "Sen, Ben ve Diğerlerinde" ise sosyete haberlerine yer vermiştir (Özen, 1990, s.59-60).

\section{Kaktüs (1988)}

Sosyalist Feminist bir kadın dergisi olan Kaktüs 1988'de yayın hayatına başlamıştır. Kitap görünümünde olan bu derginin sahibi Canan Bayraktutan'dır. Türkiye'deki kadınların durumunun yanı sıra, diğer ülkelerdeki kadınların toplumsal sorunlarına da geniş yer vermektedir. Hemen her sayısında okuyucu mektupları, söyleşi, tartışma ve yorum başlıklı sayfalar bulunmaktadır. Belirli günlerde okurlarıyla toplantılar düzenleyen derginin toplantı konuları okurlardan gelen öneriler doğrultusunda saptanmaktadır (Özen, 1990, s.59-60). 


\section{Marie Claire (1988)}

Halen Türkiye'de de yayın hayatını sürdüren moda dergisi, 1 Kasım 1988 yılında İstanbul'da İnternational Fashion Publishing tarafından yayınlanmaya başlamıştır. Derginin yayın politikası 100. sayısında bir kez daha şöyle belirtilmiştir: "Bizim dergimiz evrensel kadının dergisidir. O kadın güzelliğiyle, modayla yakından ilgilenir. Ama yayın ve uzak olaylara, gelişmelere de yabancı kalmaz, her yenilik, her değişim onun ilgi alanlarından biridir" (Yapar, 1999, s.76).

\section{Kim Dergisi (1992)}

1992 yılında yayın hayatına AD yayıncılık tarafından başlatılmıştır (Yapar, 1999, s.79). 1990'ların popüler dergilerinden olan, salt kadın bedenini veya kadın istek ve arzularını malzeme yapmayan dergi, feminizmin ilgilendiği konulara da değinmiştir. Editörlüğünü Duygu Asena'nın yaptığı derginin feminist yansımaları görülmüştür. Kim Dergisi kadın erkek eşitliği, toplumsal cinsiyet ayrımcllı̆̆ gibi konulara ironik bir biçimde değinmiştir. Bu bağlamda okuyucuları da Duygu Asena'nın tanımına göre; orta sınıf, kendi başına ayaklarının üzerinde durabilen, 20-30 yaşları arasında, hangi statüde olursa olsun modern, özgür kadınlardan oluşmaktadır (Schroeder, 2007, s.158).

\section{Cosmopolitan (1992)}

1992 yılında Bir Numara Yayıncllık tarafından aylık olarak yayınlanmaya başlanan derginin yayını, Türkiye'de dahil otuzdan fazla ülkede halen sürmektedir. Dergi Amerika'da 1883 yılından bu yana yayınlanmaktadır. Derginin içeriğinde ağırlıklı olarak cinsellik, kariyer, toplumsal ilişkiler, moda, sağlık, güzellik, dekorasyon konuları işlenmektedir ve hedef kitlesi öncelikle üniversite eğitimi görmüş, iş yaşamına atılmış başarılı kadınlardır. Cosmopolitan, "Cosmo Kız" olarak adlandırdığ 1 okur kitlesini, bağımsız, başarılı, yaşamın tüm ayrıntılarından zevk alan, eğlenmeyi ve eğlendirmeyi bilen, cinselliğini uçlarda yaşayan, evlilik ve anne sorumluluğunu bir yere kadar taşıyan biri olarak betimlemektedir (Yapar, 1999, s.78-79). 


\section{Sonuç}

Cumhuriyet dönemnde kadınlar Osmanlı dönemindeki gibi kimlik mücadelesi vermek yerine çeşitli haklar elde etmek ve fiziksel görünürlüğünü kanıtlamak için çaba sarf etmişlerdir. Bu yolda çeşitli dergilerde yazılar yazmışlardır.

Cumhuriyet dönemindeki kadın dergileri Osmanlı dönemindeki kadın dergilerinden farklı olarak diğer yazılı kaynaklar gibi toplumun değişen değeri hakkında bilgi veren yazılı kanaklardan sayılmıştır. Bu dönemde dergilerin ele aldığı konularda farklılılarında olduğu görülmektedir. Bu konular; moda, güzellik, kadı cinselliği, sağlık, eğlence, astroloji, magazine, yemek, kadın erkek eşitliği gibi konulardır. Ayrıca salt kadın bedeni ile kadın arzularını malzeme yapmayan, feminist hareketi benimseyen dergicilik anlayışına da rastlanmaktadır.

Cumhuriyet' in ilanı ile birlikte çıkarılmaya başlanan dergilerde açıkça adın hakları ve feminizm konusunun tartışılmaya başlandığı görülmektedir. Yine bu dönemde Osmanlı kadın imgelerinden farklı olarak ideal Cumhriyet kadını ve erkeklerle eşit hak ve özgürlükleri hedefleyen kadın imgeleri ele alınmaya başanmıştır.

1980 sonrası Liberalizm ve Feminist akım yayım sektörünü etkilemiş, Liberal söylemin biçimlendirdiği modern şehirli kadına kadın dergileri hitap etmeye başlamıştır. Bu dönemde teknolojinin gelişmesine paralel olarak görsel açıdan ve dergi kâğıdı açısından kaliteli malzeme kullanması reklam pastasındaki payının hatırı sayılır düzeyde artmasını sağlamıştır.

Kadın dergilerinin, teknolojinin ilerlemesi ile birlikte kağıt kalitesi ve Liberal akımla birlikte reklamcılıktaki payı gün geçtikçe artmıştır, artık ekonomik bir kol haline gelmiştir. Bu gelişmeler yeterli olmasa da Cumhuriyet dönemindeki kadın dergileri, kadının eğitimi ve haklarını arama konusunda önemli rol oynamış, günümüz kadın haklarında önemli adımların başlangıcı olmuştur. 


\title{
EXTENDED ABSTRACT
}

\section{Women's Magazines in the Republican Period (1923-1992) \\ *}

\author{
Selda Malkoç Kılıç - Duygu Vefikuluçay Yılmaz \\ Mersin University
}

Women's magazine publishing of the Republican period has started to alter gradually due to the effects of the reforms made in the country and the fact that the impact of the West is getting started to change every aspect of the society or reasons such as the sectoral revivals. Women have become visible in various fields, as a result of both obtaining rights in the political area, and the steps taken in ensuring the equality of education, and the fact that women have started to work in various branches of the business. In the magazines of pre-republican era women tried to prove their existence on the intellectual level both in their own country and before the West, and in line with this wrote articles and letters searching for their rights, and conveyed the message "we exist too". Whereas by the republican period "woman" have rather tried to prove her physical existence. This was due to the fact that the woman has gradually become visible based on the definition regarding the "Western woman" made by the Republic (Mutlu, 2009, p.59).

The scarcity or lack of the concerns of the women in the Republican period regarding identity struggle just as the Ottoman period did not originate solely from the fact that several rights were given to women. The share of the changes in the dynamics of the economy cannot be underestimated as well. These changes have led to a differentiation in the number of women's magazines, in the intervals within which they were published, and their designs and contents. Like other written materials Women's magazines were also deemed among the important sources that provide information about the changing value of society (Mutlu, 2009, p.60).

After the establishment of the Republic, it is seen that there has been a decline in the number of women's magazines between 1928 and 1940. During this period, 13 magazines were published. The adoption of the Latin 
alphabet in 1928 and the gradual gain of the women a place in the public sphere can be counted as the reasons for the decline (Schroeder, 2007, p.138).

By 1980, the women's movements which have gained power on the basis of feminism have influenced women's magazine publishing as well (Mardin, 1998, p.139). With the emergence of feminist movements and liberal policies in 1980, the publishing sector was affected and various changes occurred in the contents and outlooks of the publications. Beginning from 1980, Women's magazines appealed to the metropolitan woman formed by the liberal discourse, through handcraft examples, tips for cooking well, or topics like maternity or ways to be a good housewife, the woman in the business life, dating, education (Schroeder, 2007, p.140).

By the 1990s, expansion was observed in the market of women's magazines. It is seen that the magazines were not only of commercial type, but some of them were the publication organs of some institutions, organizations or associations. The magazines published in the late 90 s treated again subjects like mother-and-child, equality, fashion, beauty, handicrafts, the identity of Kurdish women, Islamist women, working women, and so on (Mutlu, 2009, p.62). With the advancement of technology the paper quality of the women's magazines increased, and as a result of the liberal current their share in the advertising sector grew day-by-day, thus women's magazine publishing became an industry at last.

Here is a brief overview of the magazines reviewed:

Firuze was the first women's magazine published after the proclamation of the Republic. The content of the magazine is comprised of interviews with women take part in bureaucracy, information about women painters, rules of having a beautiful body. The first women's magazine of the Republic is Süs. Süs tried to draw a woman image which corresponds to the image that the Republic attempted to create (Mutlu, 2009, p.64). 'Kadın Yolu' is the publication organ of the Turkish Women's Union, a non-governmental organization. The magazine has never had a hard attitude intended for the opposition, and this moderate attitude has had an evident impact on gaining of various rights by the women (Zihnioğlu, 2003, p.171). The publication of 'Cumhuriyet Kadını', a biweekly magazine, continued until April 1934 (Mardin, 1998, p.15). 'Kadınca' which was first published as a magazine appealing to housewives living in cities, 
then draw a more feminist outlook after Duygu Asena who is defined as a radical feminist and her team took over the publication. 'Kim', a magazine which avoids exploiting the woman body or women's wishes and desires, has mentioned the issues which concern feminism. (Schroeder, 2007, p.158). 'Elle' has handled the "woman" with her sexual identity. The magazine has drawn a working, well-groomed woman image who determines the boundary in her relations with the male by herself (Giet, 2006, p.32). 'Marie Claire', which is a fashion magazine which still continues to be published in Turkey is the magazine of the universal woman. In addition, it is a magazine that is interested in every change and innovation, and which does not remain alien to both near and remote events and developments. Sexuality, career, social relations, fashion, health, beauty, decoration are the issues handled predominantly within the content of 'Cosmopolitan' and the target audience of the magazine is primarily the successful women who are university graduates and go into the business life (Yapar, 1999, p.76). 'Rapsodi' is a magazine which includes interviews, research and review articles. The issues handled in the magazine are health, beauty, fashion, decoration. It also includes recipes. 'Kaktüs' which is socialist-feminist women's magazine is in book format and gives wide coverage to both the status of the women in Turkey and social problems of women in other countries (Ozen, 1990, p.59-60).

\section{Kaynakça / References}

Altınay, A.G. ve Arat, Y. (2007). Türkiye'de kadına yönelik şiddet. İstanbul: Punto Baskı Çözümleri.

Aşa, E. (1989). 1928'e Kadar Türk kadın mecmuaları. Yayımlanmamış Yüksek Lisans Tezi, İstanbul Üniversitesi Sosyal Bilimler Ens-titüsü, İstanbul, Türkiye.

Demirdirek, A. (1993). Osmanlı kadınlarının hayat hakkı arayışının bir hikayesi. Ankara: İmge Kitabevi.

Giet, S. (2006). Özgürlesin! Bu bir emirdir. (çev: İdil Engindeniz). İstanbul: Dharma Yayınları.

Karabacak, M. (2009). Cumhuriyet'in ilk beş yılında kadın dergileri. Yayımlanmamış Yüksek Lisans Tezi, On Dokuz Mayıs Üniversitesi Sosyal Bilimler Enstitüsü, Samsun, Türkiye. 
Kardam, F. ve Ecevit, Y. (2007). 1990'ların sonunda bir kadın iletişim kuruluşu: Uçan süpürge. A. B.-A. Günal içinde, 90'larda Türkiye'de feminizms. 2. Basım, İstanbul: İletişim Yayınları.

Mardin Davaz, A. (1998). Hanımlar Âlemi'nden Roza'ya. İstanbul: Türkiye Ekonomik ve Toplumsal Tarih Vakfi Yayınları.

Mutlu, N. (2009). Popüler kadın dergilerinde kadın temsili (örnek olay: Cosmopolitan dergisi). Yayımlanmamış Yüksek Lisans Tezi, Selçuk Üniversitesi Sosyal Bilimler Enstitüsü, Konya, Türkiye.

Özen, H. (1990). Tarihsel süreç içinde Türk kadın gazete ve dergileri (1868 1990). İstanbul: Kendi Yayını.

Şahin, E. (2018). Geçmişten günümüze kadın süreli yayınlarına karşılaştırmalı bir yaklaşım. Türk ve İslam Dünyası Sosyal araştırmalar Dergisi. 5(16), 86-105.

Schroeder, S. K. (2007). Popüler feminizm. İstanbul: Bağlam Yayınları.

Tekeli, Ş. (1990). 1980'ler Türkiye'sinde kadın bakış açısından kadınlar. İstanbul: İletişim Yayınları.

Toska, Z. (1992). İstanbul kütüphanelerindeki eski harfli Türkçe kadın dergileri bibliyografyası (1869 - 1927). İstanbul: Kadın Eserleri Kütüphanesi ve Bilgi Merkezi Vakfı.

Yapar, A. (1999). Fransa ve Türkiye'de dergicilik olgusu ve kadın dergilerinin karşılaştırılması. Yayımlanmamış Doktora Tezi, İstanbul Üniversitesi Sosyal Bilimler Enstitüsü, İstanbul, Türkiye.

Zihnioğlu, Y. (2003). Kadınsız inkılâp. İstanbul: Metis Yayınları.

https://tr.wikipedia.org/wiki/Elle_(dergi) Erişim tarihi: 20.02.2019

\section{Kaynakça Bilgisi / Citation Information}

Malkoç-Kılıç, S. ve Vefikuluçay-Yılmaz, D. (2019). Cumhuriyet dönemi kadın dergileri (1923-1992). OPUS-Uluslararası Toplum Araştırmaları Dergisi, 10(17), 2139-2156. DOI: 10.26466/opus.518421 